\title{
International Comparison of Actual Tax Burden Level of Oil and Gas Companies in China
}

\author{
Pei-hao Wu, Xin Ding \\ Business School, Sichuan University, Chengdu, Sichuan, China
}

\begin{abstract}
China oil and gas enterprises should pay huge tax and state-owned capital gains to the government apparently. In addition, they also enjoy government subsidies in different names, such as tax concessions, etc. Therefore, relationship between China oil gas enterprises and government should be clarified, therefore actual tax burden faced by China oil and gas enterprises can be measured. In the paper, six major oil and gas companies, such as CNPC, Sinopec, Gazprom, ExxonMobil, ConocoPhillips and Chevron, were selected as research objects. Overall tax burden rate, income tax burden rate and resource tax burden rate faced by the six enterprises were internationally compared. Tax level of different types in various companies were respectively measured, tax structure and government subsidy influence were compared, and suggestions of optimizing tax structure and tax burden in China oil and gas enterprises were finally proposed.
\end{abstract}

Index Terms - China oil and gas companies; tax burden; international comparison; actual tax

\section{International Comparison of Actual Tax Burden Level of China Oil and Gas Enterprises}

In the paper, four foreign enterprises of Gazprom, ExxonMobil, ConocoPhillips and Chevron were selected to compare and analyze with PetroChina and Sinopec in China in order to achieve more objective understanding on actual tax burden level of China oil and gas enterprises. These enterprises were relatively representative in international scope, which belonged to upstream and downstream integrated multinational enterprises. They are much similar in the aspects of business type, business scope, etc. with stronger comparability. In the paper, related financial data and tax data of six oil and gas enterprises, such as CNPC, Sinopec, Gazprom, ExxonMobil, ConocoPhillips and Chevron, in 2011, 2012 and 2013 were selected for comparative analysis. Actual tax burden level of China oil and gas enterprises was compared among different countries.

\section{A. International Comparison of Overall Tax Burden Rate in China Oil and Gas Enterprises \\ According to data analysis in Table 1, tax overall burden} of U.S. oil and gas enterprises was the lightest, the burden of Conocophillips and Chevron was only about $13 \%$, tax overall burden of China oil and gas enterprises was moderate, Russian oil and gas enterprises suffered from the most serious tax overall burden, namely $36.23 \%$, which was far higher than that of oil enterprises in China and the United States. As important source of Russian government finance income, oil and gas export tariff is one of the heaviest tax among taxes that should be paid by Russian oil and gas companies. Average tax burden was about $16 \%$ of operating income in recent three years. High tariff rate becomes the most important reason why gas tax burden level in Russia was much higher than that in China and the United States. It is necessary to propose tariff influence in order to analyze influence of tax burden level on enterprise overall cost burden and profitability. Oil and gas export enterprises need to pay tariffs aiming at Russian gas, thereby affecting overall tax level of enterprises. China and the United States belong to major powers for oil and gas import. Tariff is not collected for oil and gas basically. However, oil and gas tariff of export enterprises is basically transferred to export oil price, thereby import enterprise also assume tariff. Therefore, it is necessary to analyze condition after removal of tariff. Tax burden average level was $19.31 \%$ in recent three years due to influence of tariff removal on tax overall burden in Russia gas. Russia gas was in the moderate level compared with average value of $16.15 \%$ of three major enterprises in the United States and average value of $20.96 \%$ of two major enterprises in China. Tax burden level of China oil and gas enterprises was heavier, and the level in the United States was light.

\section{B. International Comparison of Enterprise Income Tax Burden Rate of China Oil and Gas Enterprises}

Data from Table 2 showed that income tax burden of three oil and gas enterprises in the United State was higher than that in China and the United States by one time or so, which was higher than $40 \%$. Income tax burden of oil and gas enterprises in China and the United States was relatively close with lighter burden lighter, about 20\%. Profit space of oil and gas enterprises in the United States was greatly reduced by income tax burden close to half of total profit. It also should be noted that corresponding income tax concessions were given to own oil and gas enterprises due to own policy support in order to sustain oil prices in China, etc. Therefore, actual income tax burden level of Petrochina and Sinopec was lower than the statutory tax rate. However, oil and gas enterprise income tax condition in the United States and Russia was contrary to Chinese enterprises. Actual tax was higher than own statutory tax rate because income tax concession policies were less for oil and gas enterprises in Russia and the United States. In addition, enterprise foreign oil and gas business income tax burden level was higher than that in own country, thereby increasing enterprise income tax burden.

\section{International Comparison of Circulation Tax Burden Rate of China Oil and Gas Enterprises}

Table 3 shows that actual burden level of VAT of domestic oil and gas enterprises was much higher than that of Russian enterprises in terms of value added tax. 
TABLE 1 International Comparison of Overall Tax Burden Rate in China Oil and Gas Enterprises (\%)

\begin{tabular}{|c|c|c|c|c|c|c|c|}
\hline \multicolumn{2}{|c|}{ Enterprise Name } & PetroChina & Sinopec & Gazprom & ExxonMobil & ConocoPhillips & Chevron \\
\hline \multirow{4}{*}{ 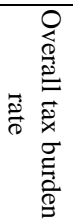 } & 2011 & 23.73 & 16.22 & 36.30 & 21.49 & 11.47 & 14.29 \\
\hline & 2012 & 25.48 & 17.94 & 35.66 & 23.52 & 11.03 & 14.71 \\
\hline & 2013 & 24.74 & 17.65 & 36.73 & 22.31 & 12.52 & 14.06 \\
\hline & $\begin{array}{c}\text { Average Value in } \\
\text { Recent Three Years }\end{array}$ & 24.65 & 17.27 & 36.23 & 22.44 & 11.67 & 14.35 \\
\hline
\end{tabular}

Data source: the data is calculated according to annual report related data of all enterprises on the basis of formula (enterprise overall tax burden rate $=$ total paid tax of enterprises/total operating income $* 100 \%)$.

TABLE 2 International Comparison of Enterprise Income Tax Burden Rate of China Oil and Gas Enterprises (\%)

\begin{tabular}{|c|c|c|c|c|c|c|c|}
\hline \multicolumn{2}{|c|}{ Enterprise Name } & PetroChina & Sinopec & Gazprom & ExxonMobil & ConocoPhillips & Chevron \\
\hline \multirow{4}{*}{$\begin{array}{l}\text { Actual Tax } \\
\text { Rate }\end{array}$} & 2011 & 20.77 & 24.98 & 20.09 & 42.39 & 46.65 & 43.30 \\
\hline & 2012 & 21.34 & 23.44 & 22.53 & 41.32 & 49.68 & 41.32 \\
\hline & 2013 & 22.16 & 24.67 & 20.83 & 42.84 & 51.24 & 42.18 \\
\hline & $\begin{array}{c}\text { Average Value in } \\
\text { Recent Three Years }\end{array}$ & 21.42 & 24.36 & 21.15 & 42.18 & 49.19 & 42.27 \\
\hline \multicolumn{2}{|c|}{ Statutory tax rate } & 25.00 & 25.00 & 20.00 & 35.00 & 35.00 & 35.00 \\
\hline
\end{tabular}

Data source: the data is calculated according to annual report related data of all enterprises on the basis of formula (enterprise income tax burden rate $=$ total paid tax of enterprises/total realized profit $* 100 \%)$.

TABLE 3 International Comparison of Circulation Tax Burden Rate of China Oil and Gas Enterprises (\%)

\begin{tabular}{|c|c|c|c|c|c|c|}
\hline \multirow[t]{2}{*}{ Year } & PetroChina & Sinopec & Gazprom & PetroChina & Sinopec & Gazprom \\
\hline & \multicolumn{3}{|c|}{ VAT } & \multicolumn{3}{|c|}{ Consumption Tax } \\
\hline 2011 & 8.94 & 7.50 & 3.78 & 4.93 & 5.03 & 1.82 \\
\hline 2012 & 7.28 & 4.56 & 3.66 & 7.56 & 5.24 & 1.78 \\
\hline 2013 & 8.43 & 5.18 & 3.58 & 5.37 & 4.98 & 1.69 \\
\hline $\begin{array}{c}\text { Average Level in Recent } \\
\text { Three Years }\end{array}$ & 8.22 & 5.75 & 3.67 & 5.95 & 5.08 & 1.76 \\
\hline
\end{tabular}

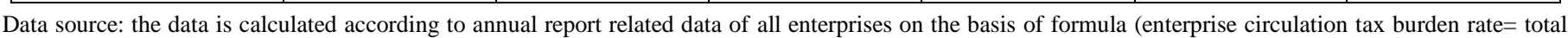
paid circulation tax of enterprises/total operating income $* 100 \%)$.

TABLE 4 International Comparison of Resource Tax of China Oil and Gas Enterprises (\%)

\begin{tabular}{|c|c|c|c|}
\hline Year & Resource Tax & Resource Exploitation Tax \\
\hline & PetroChina & Sinopec & Gazprom \\
\hline 2011 & 0.99 & 0.13 & 5.56 \\
\hline 2012 & 0.68 & 0.07 & 4.79 \\
\hline 2013 & 0.73 & 0.08 & 5.14 \\
\hline Average Value in Recent Three Years & 0.80 & 0.09 & 5.16 \\
\hline
\end{tabular}

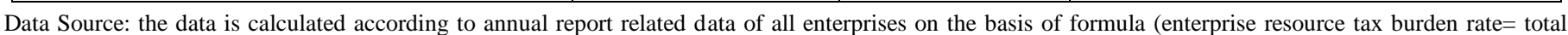
enterprise resource tax /total operating income $* 100 \%$ ).

Though Russia statutory VAT rate was $18 \%$, which was slightly higher than China VAT (17\%). However, Russia oil and gas export proportion was high due to difference in valueadded tax preferential policies. In addition, enterprise VAT overall tax level was light due to preferential policy given on oil and gas export zero tax rate, which was much lower than statutory tax rate. VAT with operating income as tax base was too heavy, which did not reflect the trend of transiting from income regulation type tax system to profit regulation system in China. VAT deduction of many assets in oil and gas enterprises was not synchronous with consumption-based VAT in China. Consumption tax of China oil and gas enterprises $(5.51 \%)$ was too heavy, which was much higher than $1.76 \%$ in Russia in the aspect of consumption tax. Since tax was calculated according to price aiming at consumption tax and consumption tax was collected in production link in China, consumption tax with high actual tax rate led to too serious fund occupation cost burden on China oil and gas enterprises due to the above collection features. 


\section{International Comparison of Resource Tax of China Oil and Gas Enterprises}

Data in Table 4 showed that resource tax tax burden level of Chinese oil and gas enterprises was extremely low, which was lower than $5.16 \%$ of Gazprom. China has low resource tax because collection of resource tax has one important role that the purpose of saving limited resources can be achieved through resource tax collection to certain extent. Oil and gas enterprises are encouraged to save resource by implementing range tax collection system. After tax reform was implemented in China, oil enterprises with different oil and gas resources are applicable to range tax rate collection regulation in resource tax collection, and resource tax is collected from quantity method. However, too low resource tax in China is not beneficial for oil and gas enterprises to save oil and gas resources.

\section{Suggestions of Optimizing Tax Structure and Tax Burden in China Oil and Gas Enterprises}

\section{A. Reducing tax burden on oil and gas enterprises,} adjusting and optimizing tax structure in China

Overall tax burden condition is analyzed. It is known that overall tax of oil enterprises in China show disadvantages in international comparison. It is not beneficial for competition of Chinese enterprises in international scope. In addition, the tax structure is also irrational. China mainly implements resource tax and consumption tax in oil tax system. Operating income is adopted as main tax basis in the two taxes. Income is mainly focused in tax collection, enterprise profit level and actual tax assumption ability are not considered due to characteristics of tax structure. China can learn from tax collection system of countries with more mature oil tax collection system such as the United States, etc. aiming at the above disadvantages. Actual conditions in China are combined for exploring direction of oil tax reform in China. Circulation tax rate can be lowered for reducing the defect of regarding operating income as tax basis in the aspect of different tax burden. Meanwhile, resource tax rate should be increased, collection link of resource tax can be adjusted, fiscal income can be obtained through tax, the role of tax in regulating market of oil and gas enterprises can be fully exerted. System design is perfected, meanwhile tax concession policies are adjusted. Flexibility of concession policies is utilized, gap can be adjusted according to actual tax burden of international oil and gas enterprises, thereby Chinese enterprises can achieve a sound competitive environment.

\section{B. Increasing proportion of enterprise income tax in total taxes, and moderately aggravating enterprise income tax burden}

Total enterprise profit is adopted as tax basis aiming at collection of enterprise income tax. The tax can be collected only under the condition that enterprises realize profit, therefore income tax can be based on actual bearing ability of enterprises. Longitudinal fair principle of tax is reflected. Superiority of income tax is also explained to certain degree. The above data is analyzed, and it is known that tax overall level is heavier in China on one hand, income tax burden in China is lighter on the other hand. It shows that Chinese tax system is not rational. Enterprise income tax can be inhibited to certain degree. Income tax concession policy on oil and gas enterprises can be reduced in China, thereby increasing actual enterprise income tax burden for oil and gas enterprises. Tax concession policies for oil and gas enterprises can be implemented in the taxes requiring macroeconomic regulation and control on oil and gas enterprises, such as encouraging oil and gas enterprises to exempt tariff in foreign investment, and concession subsidies of saving oil and gas resources.

\section{Lowering actual tax rate of VAT and consumption tax, and reducing circulation tax burden}

Relatively high value-added tax and consumption tax actual tax rate is main reason of too heavy circulation tax burden in China oil and gas enterprises. Oil enterprise exploitation process has too high uncertainty and higher risk. Risks are further increased due to VAT collection. Therefore, reduction of too heavy circulation tax actual rate is the main direction for reducing too heavy tax burden of Chinese oil and gas enterprises. In the aspect of VAT, VAT tax burden can be reduced through expanding VAT input tax deduction scope in China on one hand, VAT exemption policy can be given to a part of high risk business of oil and gas enterprises on the other hand. We can learn from mature policy of western countries for reducing actual tax burden of consumption tax. Consumption tax should be increased in the consumption link. Consumers can be affected in the consumption link, thereby realizing the purpose of adjusting consumers by consumption tax, defect of fund occupation due to collection in production link also can be avoided.

\section{Moderately increasing resource tax, and guiding market with resource tax burden}

Resource tax should be moderately increased in China, administrative awarding mechanism of oil and gas mineral right low price or free acquisition is changed, exploitation benefits of oil and gas enterprises are different due to different exploitation cycles of oil and gas enterprises. Gap in the aspect cannot be reflected in existing resource tax policy in China. Therefore, paid acquisition of mineral rights should be emphasized, thereby exerting the role of royalty and rents. Therefore, collection of mining area applicable costs with royalties property should be reinforced, collection scope of mining area should be expanded, self-operated or foreign cooperation resource exploitation are included into collection scope of mining area royalty. In addition, comparison of special proceeds in China oil and gas enterprises shows that resource compensation fee and resource tax burden are aggravated, meanwhile threshold of oil special proceeds should be suitably improved, oil enterprise tax burden should be alleviated. Flexible and preferential mining area use fee policies can be adopted aiming at foreign cooperation projects with high risks, such as unconventional oil and gas resource development, deep water exploration and development, etc. Mining area use fee is collected. Meanwhile, mineral resource 
compensation fee is increased. Mineral resource compensation fee is regarded as a kind of resource taxes. Market can be guided by utilizing resource tax tax burden.

\section{Conclusion}

Actual tax burden levels of six oil and gas enterprises, such as CNPC, Sinopec, Gazprom, ExxonMobil, ConocoPhillips and Chevron, are compared. The following conclusions are obtained. Overall tax of China oil and gas enterprises is at disadvantage position in international competition. Oil and gas tax system is mainly composed of resource tax and consumption tax. The tax structure is not rational, the tax structure leads to the result that income is more emphasized in tax collection rather than considering enterprise profit level and actual tax bearing ability, which is not beneficial for long-term development of China oil and gas enterprises. Therefore, tax burden of oil and gas enterprises should be alleviated in the paper, tax structure of China should be adjusted and optimized, proportion of enterprise income tax in overall tax should be increased, and enterprise income tax burden should be suitably increased. Actual tax rate of VAT and consumption tax should be reduced, circulation tax burden is alleviated, resource tax can be suitably increased, and resource tax can be adopted for guiding marking, thereby optimizing tax structure of China oil and gas enterprises, thereby making tax burden rational.

\section{References}

[1] Zhang Linhai. Several suggestions to promote resource tax reform in China. China Tax. 2011 (3).

[2] Pang Min, Lu Nan. Tax system comparative analysis and references between Chinese and foreign petroleum enterprises. Special Zone Economy 2011 (08).

[3] Li Feng, Wang Anyou. Research on economic compensation mechanism of resources development-mineral resource tax reform. Journal of China Mining. 2010 (02).

[4] Li Zhixue, Peng Feige, Wu Wenjie. Comparative study of domestic and foreign petroleum resource tax systems. Journal of Land and Natural Resources Research, 2010 (01).

[5] Li Yong, Speeding up tax reform and rationalizing resource price. Journal of theoretical issue. 2010 (10).

[6] Li Jing, Wang Lin. Analysis and design of oil tax system reform in China. Journal of Modern Business. 2010 (33).

[7] Li Xuhong. Contrast and reference of Chinese and foreign petroleum tax system. Journal of Guangxi University (Philosophy and Social Sciences Edition), 2010 (01).

[8] Pang Min, Lu Nan. Comparative analysis and reference of tax system between Chinese and foreign oil enterprises. Special Zone Economy. $2011(08)$. 